\title{
Cyclic variation of the cellular components in human uterine fluid
}

\author{
B. Casslén, T. K. Kobayashi* and N. Stormby* \\ Departments of Obstetrics and Gynecology, and ${ }^{*}$ Clinical Cytology, Malmö Allmänna Sjukhus, \\ 21401 Malmö, Sweden
}

\begin{abstract}
Summary. Endometrial glandular cells and mononuclear phagocytic cells dominated the samples of undiluted uterine fluid obtained at different stages of the menstrual cycle whereas granulocytes were present in much lower numbers. Mast cells were occasionally found. The number of each cell type was significantly decreased in the luteal phase as compared to the midcycle and premenstrual phases. Phagocytic activity of the mononuclear cells was also significantly decreased in the luteal phase. Low numbers of inflammatory cells and low phagocytic activity during the luteal phase may be important for survival of the blastocyst in the event of conception.
\end{abstract}

\section{Introduction}

Cells of the mononuclear phagocytic system are present in the human endometrial stroma, and have variously been called stromal macrophages, interstitial mononuclear cells, and histiocytes. According to experimental data, both their number and phagocytic activity are increased by oestrogenic stimuli, and this effect is reportedly not inhibited by progesterone (VernonRoberts, 1969). These cells also increase in the endometrial stroma premenstrually (Baron \& Esterly, 1975), and in the uterine discharge postmenstrually (Papanicolaou, 1953). Eosinophilic granulocytes have been reported to appear in the uterus following very low doses of oestrogen (Bjersing \& Borglin, 1964; Tchernitchin, Tchernitchin \& Galand, 1976). Some authors have found them in highest numbers in the human endometrium during the proliferative phase (van Bogaert, 1975; van Bogaert \& Maldague, 1979), but others have found them mainly during the luteal phase, following stimulation with progesterone and during early pregnancy (Hellweg, Ferin \& Ober, 1960; Kazzaz, 1972).

If macrophages and granulocytes are considered as parts of the gonadal steroid receptor system, then these cells may influence various aspects of the reproductive process. Migration and maturation of spermatozoa at midcycle and storage of the preimplantation blastocyst, will be influenced by the cells in the uterine fluid and by the potent enzymes released by these cells. This study was designed to count the cells in human uterine fluid obtained during the various phases of the menstrual cycle.

\section{Materials and Methods}

Clinical material. This consisted of 48 healthy women attending our clinic for contraceptive counselling. They were aged 20-40 years, menstruating at about 4 -week intervals, and were not using intrauterine devices or oral contraceptives. Parous and non-parous women were included. 
All had uteri of normal size. One sample of uterine fluid was obtained from each woman. The samples were classified according to the day of the menstrual cycle as belonging to the proliferative phase (the day after the last day of bleeding until the 10th day of the cycle), the midcycle phase (11th-16th day of the cycle), the luteal phase (17th day of the cycle until 4 days before the onset of menstruation), and the premenstrual phase (the 3 days before onset of menstruation). Using these criteria, 16 women were in the proliferative phase, 16 in the midcycle, 12 in the luteal and 4 in the premenstrual phase.

Samples of uterine fluid. A pediatric feeding tube (o.d. $3 \mathrm{~mm}$, i.d. $2 \mathrm{~mm}$ ) connected to a syringe aspirator as previously described was introduced into the uterine cavity under sterile conditons and a low negative pressure was applied (Casslén 1981). In this way damage to the endometrium was avoided, and a portion of the pure uterine fluid could be aspirated in most women. Samples contaminated with blood or cervical mucus were discarded.

Cell counting. A $1 \mu \mathrm{l}$ aliquot from each sample was immediately dispersed between two glass slides. The slides were fixed in $70 \%$ ethanol and stained with a modified Papanicolaou technique. All cells on both slides were counted under low magnification $(\times 100)$. For differential counts of the cells the smears were stained with May-Grünwald-Giemsa (MGG). The mean value for each cell type in a total of $4 \times 100$ cells was calculated. For each cell type the number of cells per $\mu \mathrm{l}$ uterine fluid was then calculated from the total number of cells per $\mu$ l multiplied by the percentage for each cell type. The occurrence of mast cells was examined in smears, which were air dried, fixed in methanol for $5 \mathrm{~min}$ and stained with eosin (Eosino-stain, Torii Co. Ltd, Tokyo, Japan) as described by Hansel (1953).

Phagocytic activity of the mononuclear phagocytic cells. Smears were stained with MGG and 200 cells were examined. The mean number of cells with phagocytosed material was taken as a measure of the phagocytic activity. Further, staining with naphthol AS-D chloroacetate (Yam, Li \& Crosby, 1971) was used to demonstrate the presence of granulocyte fragments in the mononuclear phagocytic cells.

Statistical methods. The differences between the numbers of cells in the 4 menstrual phases were evaluated using Wilcoxon's rank sum test. When comparing the numbers of different cell types within each menstrual phase Student's $t$ test for paired observations was used. The correlation coefficient $(r)$ between the number of each individual cell type and the total number of cells was calculated.

\section{Results}

\section{Cell counts}

The results are shown in Text-figs 1 and 2 and Table 1. The number of each individual cell type was significantly $(P<0.001)$ correlated to the total number of cells $(r=0.71-0.82)$. The number of mononuclear phagocytic cells was not significantly different from the number of endometrial glandular cells. The number of granulocytes was lower $(P<0.001)$ than the numbers of mononuclear phagocytic cells and endometrial glandular cells. The eosinophilic granulocytes composed $0-1 \%$ of the total number of granulocytes in all but two of the samples. In these two samples, which were obtained in the proliferative phase, eosinophils composed 7 and $38 \%$ of the granulocytes respectively. Mast cells were present in 1 sample in the proliferative phase, in 3 samples in the midcycle phase and in 1 sample in the luteal phase. When present, only 1-4 mast cells/ $\mu$ l fluid were found.

\section{Phagocytic activity of the mononuclear cells}

The presence of positively stained material in the cytoplasm after staining with MGG was frequent. Ingested material often consisted of granulocyte fragments, as shown by staining 
Table 1. Mean values for the cell counts (per $\mu \mathrm{l}$ uterine fluid) given in Text-figs 1 and 2

\begin{tabular}{lcccc}
\hline & Proliferative & Midcycle & Luteal & Premenstrual \\
\hline Total cells & 833 & $752^{*}$ & 59 & $1226^{*}$ \\
Mononuclear phagocytic cells & 174 & $128^{*}$ & 9 & $221^{\dagger}$ \\
Endometrial glandular cells & 121 & $509^{*}$ & 50 & $927^{*}$ \\
Granulocytes & 42 & $32^{*}$ & 2 & $79^{*}$ \\
Other cells $\ddagger$ & 24 & $37^{*}$ & 5 & 0 \\
\hline
\end{tabular}

* Value significantly different from that in the luteal phase, $P<0.01$.

$\dagger$ Value significantly different from that in the luteal phase, $P<0.02$.

$\ddagger$ Included stromal cells, lymphoid cells, some plasma cells and some unclassified cells.

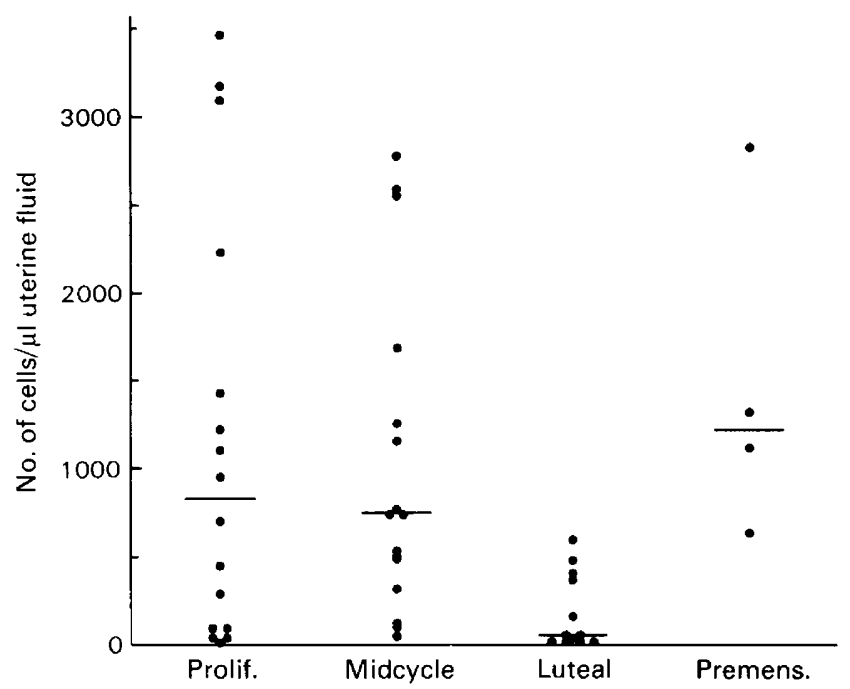

Text-fig. 1. Total numbers of cells in uterine fluid from women at different phases of the menstrual cycle. The horizontal bars indicate the median numbers (see Table 1).

with naphthol AS-D chloroacetate. The number of positively stained cells was always lower with the naphthol AS-D chloroacetate staining than with MGG staining. The percentage of mononuclear cells with ingested material varied throughout the menstrual cycle (Text-fig. 3). There were $32 \%$ (median) in the proliferative phase, $21 \%$ in the midcycle phase, $11 \%$ in the luteal phase and $14 \%$ in the premenstrual phase. The activity during the luteal phase was lower $(P<0.01)$ than that of the midcycle phase.

\section{Discussion}

The concentration of cells in uterine fluid was lower in the luteal phase than in the proliferative, midcycle or premenstrual phases. No comparable study has been reported. Decreased cell counts in the luteal phase may arise from dilution with an increased volume of uterine fluid or decrease of the total number of cells in the uterine cavity. However, the volume of uterine fluid is reportedly not increased, but decreased in the luteal phase, probably due to resorption of water (Clemetson, Kim, de Jesus, Mallikarjuneswara \& Wilds, 1973). This is further supported by the 


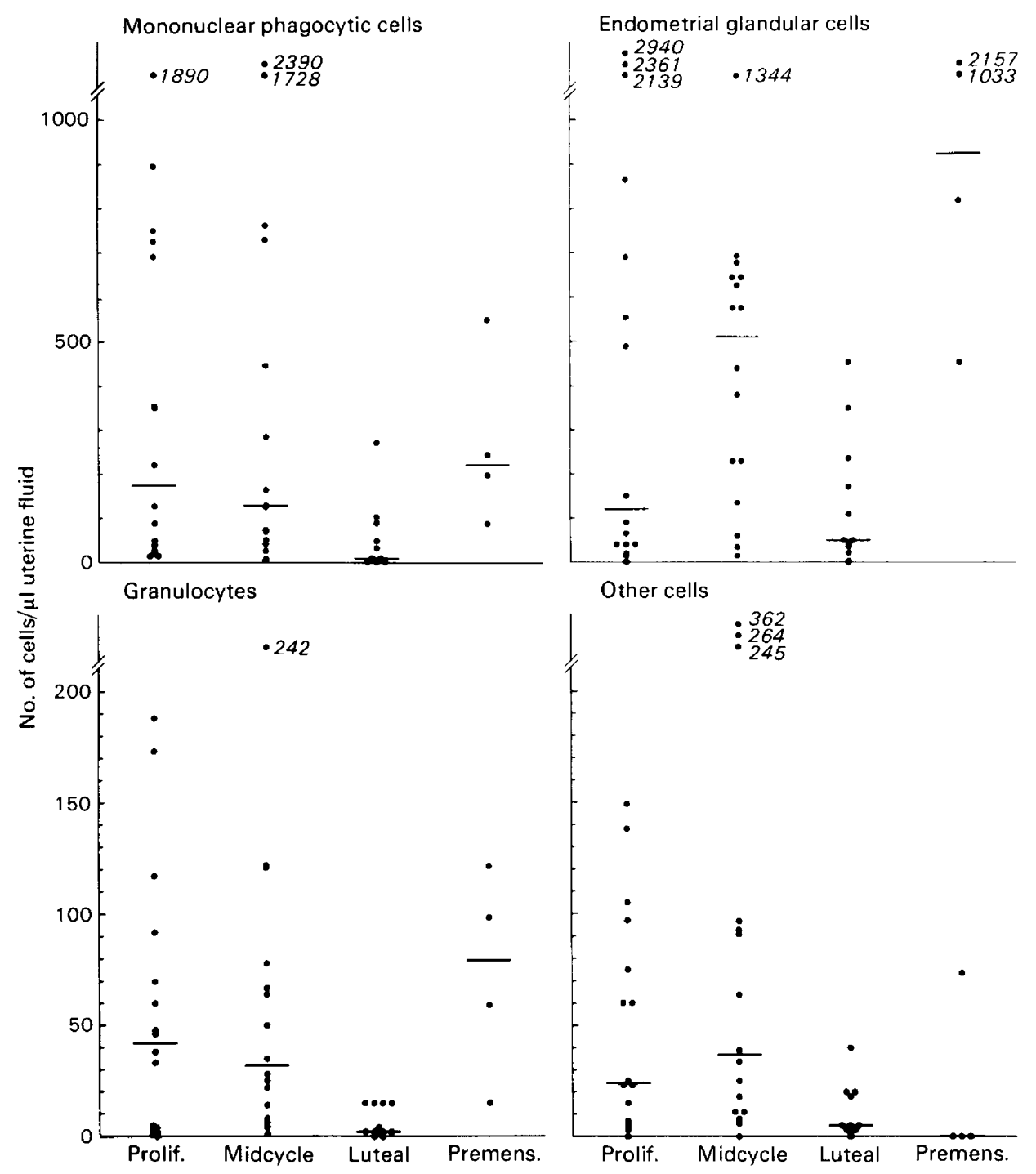

Text-fig. 2. Counts of various cell types in uterine fluid from women at different phases of the menstrual cycle. The horizontal bars indicate the median numbers (see Table 1).

finding of increased concentrations of some serum proteins in the luteal phase (Casslen \& Ohlsson, 1981). Therefore, although the total numbers of cells in the uterine cavity were not calculated, it is suggested that not only the concentration of cells, but also the total number of cells is decreased in the luteal phase.

To our knowledge, there is no previous report of hormonal influences on the presence of macrophages and granulocytes in human uterine fluid. We obtained lower counts of granulocytes and mononuclear phagocytic cells in the luteal phase than in the proliferative and midcycle phases. Higher counts of granulocytes during the proliferative and midcycle phases are comparable to the results for eosinophilic granulocytes in the endometrium (van Bogaert, 1975; van Bogaert \& Maldague, 1979). However, our data on uterine fluid do not favour the hypothesis that eosinophilic granulocytes should represent a specific oestrogen-sensitive cell 


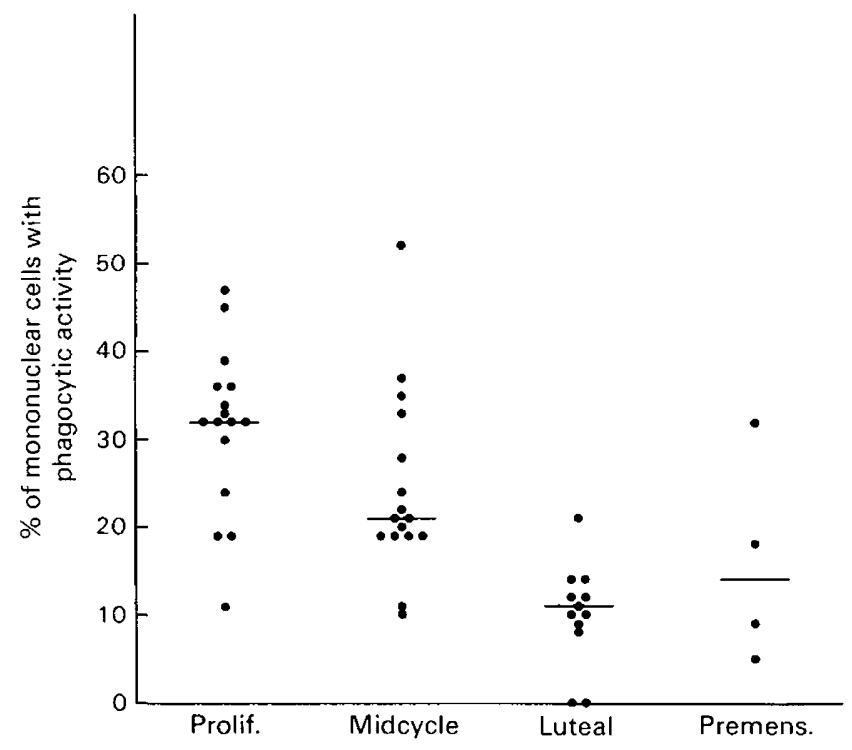

Text-fig. 3. Phagocytic activity of the mononuclear cells in human uterine fluid during the menstrual cycle. The horizontal bars indicate the median percentages.

system, since they constituted less than $1 \%$ of the total number of granulocytes in all cyclic phases. Variations in the number of eosinophilic granulocytes in the uterine tissues (Bjersing \& Borglin, 1962; van Bogaert \& Maldague, 1979) may be secondary to variations of the total number of granulocytes, which may be difficult to detect in histological sections. The finding of considerably higher percentages of eosinophils in two uterine fluid samples may possibly be explained by unknown minor trauma to the uterus (Bjersing \& Borglin, 1962).

High numbers of mononuclear cells were present in the uterine fluid during both proliferative and midcycle phases. This is a more extended period than was reported after examination of vaginal smears (Papanicolaou, 1953). Our findings are supported by a report on the cyclic pattern of the number of macrophages present on intrauterine devices (Foley, Jenkins \& McNicol, 1978), and by the observation that both the number and phagocytic activity of macrophages is stimulated by oestrogen (Vernon-Roberts, 1969). However, in contrast to the latter report, we found decreased numbers of macrophages in the luteal phase.

There are conflicting views on the cyclic variation of mast cell numbers in the endometrium (Sheppard \& Bonnar, 1979). The occurrence of mast cells in the uterine cavity has previously been reported only in connection with the inflammatory reaction associated with the use of an intrauterine device (Kobayashi, Okamoto, Harami \& Yuasa, 1980). Our study has shown that mast cells are scarce in normal uterine fluid.

The intrauterine stages of the reproductive process, namely passage and maturation of spermatozoa and storage of the preimplantation blastocyst, may differ in their susceptibility to inflammatory cells. Although macrophages are present in high numbers and phagocytosis of spermatozoa by these cells occurs in the uterine cavity of women fitted with an intrauterine device (Sagiroglu \& Sagiroglu, 1970; Gupta, Malkani \& Bhasin, 1971), passage of spermatozoa to the oviducts also occurs in these patients (Morgenstern, Orgebin-Crist, Clewe, Bonney \& Noyes, 1966; Croxatto et al., 1973). Therefore, the passage of spermatozoa through the uterine cavity is probably unaffected by the phagocytic cells which are present in comparably low numbers in normal uterine fluid at midcycle. The preimplantation blastocyst seems to be more susceptible to inflammatory cells in the uterine fluid (Parr \& Shirley, 1976). The fact that it 
spends a comparably long period unattached in the uterine cavity may contribute to this. The low number of granulocytes and mononuclear phagocytic cells found in uterine fluid during the luteal phase probably represents a physiological mechanism that helps to protect the blastocyst in the event of conception. This hypothesis gains further support by the finding of decreased phagocytic activity of the mononuclear cells during the luteal phase.

\section{References}

Baron, D.A. \& Esterly, J.R. (1975) Histochemical demonstration of lysosomal hydrolase activity in endometrial mononuclear cells. I. Normal endometrium. II. Abnorml endometrium. Am. J. Obstet. Gynec. 123, 790-803.

Bjersing, L. \& Borglin, N.E. (1962) Eosinophilia in the myometrium of the human uterus. Acta path. microbiol. Scand. 54, 353-364.

Bjersing, L. \& Borglin, N.E. (1964) Effect of hormones on incidence of uterine eosinophilia in rats. Acta path. microbiol. Scand. 60, 27-35.

Casslén, B. (1981) Proteinases and proteinase inhibitors in uterine fluid, with special reference to IUD-users. Acta obstet. gynec. Scand., Suppl. 98.

Casslén, B. \& Ohlsson, K. (1981) Cyclic variation of proteinase inhibitors in human uterine fluid and influence of an IUD. Contraception 23, 425-434.

Clemetson, C.A.B., Kim, J.K., de Jesus, T.P.S., Mallikarjuneswara, V.R. \& Wilds, J.H. (1973) Human uterine fluid potassium and the menstrual cycle. $B r$. J. Obstet. Gynaec. 80, 553-561.

Croxatto, H.B., Faundes, A., Medel, M., Avendano, S., Croxatto, H.D., Vera, C., Anselmo, J. \& Pastene, J. (1973) Studies on sperm migration in the human female genital tract. In The Biology of Spermatozoa, pp. 56-62. Karger, Basle.

Foley, M.E., Jenkins, D.M. \& McNicol, G.P. (1978) Production of fibrinolytic enzymes by macrophages on intrauterine contraceptive devices. Br. J. Obstet. Gynaec. 85, 551-556.

Gupta, P.K., Malkani, P.K. \& Bhasin, K. (1971) Cellular response in the uterine cavity after IUD insertion and structural changes of the IUD. Contraception 4, 375-384.

Hansel, F.K. (1953) Clinical Allergy, pp. 408-419. C.V. Mosby, St Louis.

Hellweg, G., Ferin, J. \& Ober, K.G. (1960) Über die Bildung von endometrialen körnchencellen bei Kastratinnen unter Hormoneinfluss. Acta endocr., Copenh. 33, 261-276.
Kazzaz, B.A. (1972) Specific endometrial granular cells. A semiquantitative study. Eur. J. Obstet. Gynec. 3, 77-84.

Kobayashi, T.K., Okamoto, H., Harami, K. \& Yuasa, M. $(1980)$ The presence of mast cells in IUD smears. Acta cytol. 24, 268-269.

Morgenstern, L.L., Orgebin-Crist, M.-C., Clewe, T.H., Bonney, W.A. \& Noyes, R.W. (1966) Observations on spermatozoa in the human uterus and oviducts in the chronic presence of intrauterine devices. $A m . J$. Obstet. Gynec. 96, 114-118.

Papanicolaou, G.N. (1953) Observations on the origin and specific function of the histiocytes in the female genital tract. Fert. Steril. 4, 472-478.

Parr, E.L. \& Shirley, R.L. (1976) Embryotoxicity of leukocyte extracts and its relationship to intrauterine contraception in humans. Fert. Steril. 27, 10671077.

Sagiroglu, N. \& Sagiroglu, E. (1970) Biologic mode of action of Lippes loop in intrauterine contraception. Am. J. Obstet. Gynec. 106, 506-515.

Sheppard, B.L. \& Bonnar, J. (1979) Mast cells in the human uterus. In The Mast Cell and its Role in Health and Disease, pp. 142-148. Eds J. Pepys \& A. M. Edwards. Pitman Medical, Tunbridge Wells.

Tchernitchin, X., Tchernitchin, A. \& Galand, P. (1976) Dynamics of eosinophils in the uterus after oestrogen administration. Differentiation 5, 151-154.

van Bogaert, L.J. (1975) Endometrial granulocytes in proliferative endometrium. Br. J. Obstet. Gynaec. 82, 995-998.

van Bogaert, L.J. \& Maldague, P. (1979) Granulocytes in the endometrium of post-partum women. $J$. Reprod. Fert. 57, 97-100.

Vernon-Roberts, B. (1969) The effects of steroid hormones on macrophage activity. Int. Rev. Cytol. 25, 131-159.

Yam, L.T., Li, C.Y. \& Crosby, W.H. (1971) Cytochemical identification of monocytes and granulocytes. Am. J. clin. Path. 55, 283-290. 